\title{
ANALISIS PERMINTAAN ENERGI LISTRIK RUMAH TANGGA (STUDI KASUS : RUMAH TANGGA DI KOTA BENGKULU
}

\author{
Nilman ${ }^{1)}$, Mintargo ${ }^{2)}$ \\ ${ }^{1}$ Jurusan Ekonomi Pembangunan Fakultas Ekonomi Dan Bisnis Universitas Bengkulu \\ Email: nilman20031997@gmail.com \\ 2 Jurusan Ekonomi Pembangunan Fakultas Ekonomi Dan Bisnis Universitas Bengkulu \\ Email: mintargo@unib.ac.id
}

\begin{abstract}
This study aims to analyze the factors that influence the demand for electrical energy in households in the city of Bengkulu. With the dependent variable $(Y)$ the demand for electrical energy and the independent variable (X) Income, electricity priceltariff, number of family members. In this study using primary data with a total sample of 100 households in the city of Bengkulu. The data analysis method used is multiple linear regression. From the analysis that has been done the results show that the income variable (X1) has a significant and positive effect on the demand for electricity, electricity prices/tariffs (X2) have a significant and negative effect on the demand for electrical energy and the number of family members (X3) has a significant and positive effect on demand for electrical energy.
\end{abstract}

Keywords: Demand for electrical energy, Electricity priceltariff ,Income, Number of family members.

\section{PENDAHULUAN}

Pembangunan nasional pada dasarnya dilakukan untuk memenuhi kesejahteraan hidup seluruh lapisan masyarakat, sehingga nantinya dapat membawa perubahan diberbagai sistem sosial seperti politik, ekonomi, infrastruktur, pendidikan, dan teknologi (Alexander, 1994). Seperti yang tercantum dalam pasal 33 ayat 3 Undang-Undang Dasar 1945, bahwa "Kekayaan bumi seperti sumber daya alam dan energi yang terkandung didalamnya dikuasai oleh negara dan dipergunakan sebesar-besarnya untuk kemakmuran rakyat".

Energi merupakan sumberdaya yang sangat dibutuhkan dalam kehidupan dan juga dibutuhkan dalam proses pembangunan, terutama untuk mendukung proses industrialisasi. Pembangunan energi ini mencakup berbagai aspek salah satu diantaranya adalah pembangunan energi listrik yang diarahkan untuk mendorong kegiatan pembangunan ekonomi dan meningkatkan kesejahteraan masyarakat (Nuryanti, 2007). Energi listrik merupakan sumber energi yang penting bagi kehidupan manusia baik untuk kegiatan industri, kegiatan komersial, maupun dalam kehidupan sehari-hari rumah tangga (Saepudin, 2013).

Di era globalisasi ini, masyarakat sangat tergantung pada energi listrik. Dimana energi listrik tidak lagi sekedar menjadi kebutuhan sekunder, tetapi sudah menjadi kebutuhan primer. Kebutuhan energi listrik tidak hanya untuk kepentingan pemerintah dan pengusaha saja, namum juga dibutuhkan oleh kalangan profesi lainya, termasuk rumah tangga. Listrik saat ini bertambah fungsinya dalam masyarakat, dimana listrik tidak hanya dipakai sebagai sumber energi untuk penerangan saja. Tetapi telah berkembang sedemikian rupa sehingga listrik telah digunakan untuk fungsi lainnya, seperti sumber energi untuk mendapatkan informasi, transportasi, hiburan dan bahkan untuk mempermudah kegiatan rumah tangga sehari-hari. Tanpa listrik masyarakat sulit beraktifitas. Jika masyarakat sulit beraktivitas maka kegiatan ekonomi akan tertanggu dan keadaan ini tentunya akan memengaruhi pembangunan ekonomi negara. 
Mengingat begitu besar dan pentingnya manfaat energi listrik sedangkan sumber energi pembangkit listrik terutama yang berasal dari sumber tak terbarui ketersediaannya semakin terbatas, maka untuk menjaga kelestarian seumber energi perlu diupayakan langkah strategis yang dapat menunjang penyediaan enegi listrik secara optimal dan terjangkau. Dimana kita ketahui bahwa energi listrik memainkan peran penting dalam perkembangan ekonomi dan menjadi faktor penting yang menompang kesejahteraan rakyat

Tabel 1 Banyaknya Jumlah Pelanggan, Daya, kWh Terjual di Provinsi Bengkulu, 2014-2018.

\begin{tabular}{cccc}
\hline Tahun & Pelanggan & Daya (VA) & kWh Terjual \\
\hline 2014 & 405.649 & 424.549 .018 & 641.513 .202 \\
2015 & 430.876 & 461.768 .418 & 795.347 .937 \\
2016 & 457.071 & 502.744 .768 & 824.874 .812 \\
2017 & 490.356 & 554.388 .768 & 852.841 .013 \\
\hline
\end{tabular}

Sumber : PT. PLN (Persero) UP3 Bengkulu, 2018

Berdasarkan Tabel 1 diatas menggambarkan bahwa permintaan energi listrik di Provinsi Bengkulu terus meningkat setiap tahunnya ini terlihat dari meningkatnya jumlah pelanggan listrik, daya (VA) dan kwh terjualnya. Dimana Peningkatan pelanggan dari tahun 2014 jumlah pelangganya mencapai 405.649 menjadi 490.356 pelanggan pada saat tahun 2017, Sementara daya terpasang juga terus meningkat dari tahun 2014 yaitu sebesar 424.549.018 volt amper sampai pada tahun 2017 mencapai 554.388.768 volt amper. Penambahan daya listrik ini dilakukan karena untuk mengimbangi jumlah pelanggan listrik yang terus meningkat, sehingga untuk menemuhi kebutuhan ini PLN harus menambahkan jumlah produksinya. Dan dari data kwh yang terjual juga terus terjadi peningkatan dimana pada tahun 2014 sebesar $641.513 .202 \mathrm{kwh}$, terus meningkat hingga pada tahun terakhir 2017 yang data kwh terjualnya mencapai $852.841 .013 \mathrm{kwh}$.

Pertumbuhan penduduk dan juga pertumbuhan ekonomi menjadi salah satu faktor penyebab meningkatnya permintaan energi listrik pada masyarakat Bengkulu saat ini, seiring dengan meningkatnyan kesejahteraan masyarakat dan semakin cepatnya perkembangan teknologi. Dari situasi ini sebenarnya PT.PLN dapat memperoleh keuntungan yang bersar dari penjualan listrik pada masyarakat. Tetapi tetap saja dalam pemenuhan kebutuhan listrik PLN masih belum mampu untuk memenuhi kebutuhan listrik tersebut sehingga energi listrik saat ini belum dapat dinikmati sepenuhnya oleh masyarakat Bengkulu.

Hal ini disebabkan karena sistem kelistrikan Bengkulu masih termasuk kedalam jaringan interkoneksi dari Sumatera Selatan - Jambi dan Bengkulu (WS2JB) dimana Pusat pengendalian distribusi listriknya berada di Sumatera Selatan, sehingga Propinsi Bengkulu tidak mempuyai kewewenangan untuk menentukan berapa besar daya diperlukan agar kebutuhan listrik Bengkulu terpenuhi maka jalur interkoneksi ini merugikan rakyat Bengkulu. Selain itu juga hal ini dikarenakan keterbatasan yang dimiliki oleh PLN, dimana dari data RUPTL (Rencana Usaha Penyedian Tenaga Listrik) permasalahan utama listrik bengkulu disebabkan karena jaringan transmisi, gardu induk dan sistem distribusi yang ada dibengkulu saat ini juga masih belum memadai sehingga dalam pemenuhan kebutuhan listrik ini juga masih terbatas.

Untuk memenuhi kebutuhan listrik masyarakat Bengkulu kebijakan yang dilakukan oleh pemerintan adalah dimana berdasarkan dokumen RUPTL PLN 2017-2026, Bengkulu direncanakan akan dilakukan pembangunan 14 pembangkit listrik, 2 pembangkit besar diatas $100 \mathrm{MW}$, sisanya pembangkit berkapasitas antara 4-80 MW. Dari 14 pembangkit tersebut 13 berasal dari energi yang relative bersih seperti air, panas bumi,uap, biomasa dan minihidro. Denga adanya kebijakan 
ini maka kebutuhan listrik dimasa yang akan datang akan bisa terpenuhi sehingga dapat dinikmati sepenuhnya oleh masyarakat.

Kota Bengkulu merupakan kota sekaligus ibu kota di Provinsi Bengkulu, dengan jumlah penduduk sebesar 368.065 jiwa dengan kepadatan penduduk yang mencapai 2,42 perkilometer persegi. Kota Bengkulu juga salah satu kota yang secara rata-rata penduduknya sudah menggunakan energi listrik dan termasuk pelanggan dengan permintaan energi listrik terbanyak. Berikut tabel yang menunjukan jumlah pelanggan rumah tangga dan pemakaian listrik per kwh di Kota Bengkulu.

Tabel 2 Pertumbuhan Jumlah Pelanggan R dan kWh Terjual di Kota Bengkulu Tahun 2014-2018

\begin{tabular}{ccc}
\hline Tahun & Jumlah Pelanggan & kWh Terjual \\
\hline 2014 & $8,70 \%$ & $13,19 \%$ \\
2015 & $8,03 \%$ & $6,80 \%$ \\
2016 & $8,12 \%$ & $4,24 \%$ \\
2017 & $8,10 \%$ & $0,80 \%$ \\
2018 & $10,0 \%$ & $8,01 \%$ \\
\hline
\end{tabular}

Sumber : PT. PLN (Persero) UP3 Bengkulu, 2018

Berdasarkan dari Tabel 2 menggambarkan bahwa permintaan energi listrik pada rumah tangga di Kota Bengkulu dari tahun 2014-2018 mengalami fluktuasi setiap tahunnya terlihat dari pertumbuhan jumlah pelanggan dan kwh terjualnya. Dimana pada tahun 2014 persentase jumlah pelanggan mencapai 8,70\% dan menurun pada tahun 2015 dimana jumlah pelanggan mencapai 8,03\% dan meningkat kembali pada tahun 2016 mencapai 8,12\% hingga pada tahun 2018 persentase pertumbuhan jumlah pelanggan mencapai $10,0 \%$. Sementara pada jumlah energi listrik yang terjual juga mengalami fluktuasi dimana pada tahun $2014 \mathrm{kwh}$ yang terjual mencapai $1,36 \%$ dan meningkat pada tahun 2015 yang dimna persentase kenaikannya mencapai 6,80\% hingga tahun 2018.

Peningkatan permintaan/pemakaian energi listrik juga dipengaruhi oleh beberapa variabel, seperti: jumlah anggota keluarga, pendapatan, harga /tarif energi listrik dan jumlah peralatan listrik yang digunakan. Pertambahan penduduk di Kota Bengkulu yang semakin meningkat akan menyebabkan bertambahnya permintaan energi listrik. Karena dalam satu rumah tangga saja, pertambahan anggota keluarga dapat menyebabkan peningkatan penggunaan listrik. Karena setiap individu pasti akan menggunakan tenaga listrik untuk membantu kegiatan sehari-hari. apalagi zaman sekarang ini, semua peralatan rumah tangga hampir semuanya menggunakan listrik. Sehingga pertambahan jumlah anggota keluarga akan mempengharui jumlah konsumsi listrik. Dengan meningkatnya jumlah anggota keluarga maka kebutuhan akan penggunaan alat-alat listrik juga meningkat.

Pendapatan juga merupakan salah satu faktor yang menyebabkan bertambahnya permintaan/ pemakaian akan listrik. Menurut Bjoner et.al, (2006) Pendapatan merupakan variabel independen utama yang berpengaruh terhadap permintaan energi listrik. Jika pendapatan dalam suatu rumah tangga tinggi maka keinginan untuk menambah jumlah daya listrik juga ikut meningkat begitu juga dengan sebaliknya. Hubungan kedua variabel itu, antara pendapatan rumah tangga dengan jumlah permintaan atas suatu barang tergantung pada jenis dan sifat barangnya.

Permintaan energi listrik juga dipengaruhi oleh harga/tarif listrik. Dalam analisis permintaan energi listrik rumah tangga, listrik diasumsikan dan termasuk barang normal. Oleh karena itu, 
perubahan harga atau tarif langsung mempengaruhi tingkat pendapatan. Jika harga listrik naik, konsumen rumah tangga akan mengurangi permintaan atau pemakaian energi listrik karena kenaikan harga ini menyebabkan pendapatan riilnya turun yang sekaligus mengurangi daya beli (Langmore \& Dufty, 2004).

Mengingat karena energi listrik saat ini sudah menjadi kebutuan dasar dan sangat vital dalam kehidupan sehari-hari. Dan begitu tingginya permintaan akan kebutuhan energi listrik seiring dengan meningkatnya pertumbuhan ekonomi dan pertumbuhan penduduk, Namun dalam pemenuhan kebutuhan energi listrik saat ini tetap saja terjadi kekurangan dalam penyediaannya, sehingga perlu adanya tambahan beberapa pembangkit listrik agar penyediaan listrik bisa memenuhi kebutuhan tersebut.

Selain itu peningkatan permintaan /pemakaian energi listrik tersebut juga dipengaruhi oleh beberapa variabel, seperti: jumlah anggota keluarga, pendapatan, harga/tarif energi listrik dikenakan. Melihat fenomena ini maka penulis tertarik untuk mengangkat permasalahan energi listrik ini kedalam suatu penelitian yang berjudul " Analisis faktor-faktor yang mempengharui permintaan energi listrik pada rumah tangga di Kota Bengkulu". Dengan tujuan untuk mengetahui pengaruh pendapatan, harga/ tarif listrik dan jumlah anggota keluarga terhadap permintaan energi listrik pada rumah tangga di Kota Bengkulu.

\section{LANDASAN TEORI}

\section{Teori Permintaan}

Permintaan menurut ilmu ekonomi diartikan sebagai jumlah barang yang dibeli oleh sejumlah konsumen dengan harga tertentu pada waktu dan tempat tertentu (Samuelson dkk, 2003). Sedangkan menurut Sukirno (2013) permintaan adalah sejumlah barang yang diminta oleh konsumen yang diinginkan dan sanggup untuk membelinya pada berbagai tingkatan harga satuan barang tersebut. Permintaan seseorang atau suatu masyarakat atas suatu barang ditentukan oleh banyak faktor-faktor antara lain ;

\section{a. Harga barang itu sendiri}

Harga memiliki peranan yang sangat penting dalam mempengaruhi keputusan konsumen dalam membeli produk, sehingga sangat menentukan keberhasilan permintaan suatu produk (Rahardja dan Manurung, 2001). Naik turunnya harga suatu barang atau jasa akan mempengharui banyak atau sedikitnya terhadap jumlah barang yang diminta. Bila harga naik maka permintaan turun dan sebaliknya bila harga turun permintaan akan naik dengan asumsi ceteris paribus.

Hubungan perubahan harga terhadap permintaan mempuyai arah yang berkebalikan. Harga barang yang lebih murah akan menarik minat masyarakat untuk membeli barang tersebut dibandingkan membeli barang sejenisnya dengan harga yang lebih tinggi (Sukirno, 2013).

b. Harga barang lain

Harga barang lain yang mempengaruhi permintaan ada dua yaitu :

1. Harga barang pengganti (subtitusi)

Suatu barang dinamakan barang pengganti kepada barang utama apabila ia dapat menggantikan fungsi barang utama tersebut. Konsumen akan membatasi pembali jumlah barang yang diinginkan apabila harga barang terlalu tinggi, bahkan ada kemungkinan konsumen memindahkan konsumsi dan pembelinya kepada barang penggangti yang lebih murah hargannya. Harga barang pengganti dapat mempengharui permintaan barang yang dapat digantikannya. Sekirannya harga barang pengganti bertambah murah maka barang digantikannya akan mengalami pengurangan dalam permintaan (Sukirno, 2013). 
2. Harga barang pelengkap (komplementer).

Apabila suatu barang selalu digunakan bersama dengan barang lainnya, maka barang tersebut dinama barang pelengkap kepada barang utama tersebut. Menurut Rahardja dan Manurung (2001) harga barang komplementer juga akan mempengaruhi keputusan seorang konsumen untuk memebeli atau tidak barang utamanya. Kenaikan dan penuruan permintaan terhadap barang pelengkap selalu sejalan dengan perubahan permintaan barang yang digenapinya (Sukirno, 2013)

\section{c. Jumlah Penduduk}

Secara tidak langsung pertambahan penduduk diikuti dengan perkembangan dalam kesempatan kerja sehingga akan meningkatkan daya beli dan permintaan (Sukirno, 2013). Semakin banyak jumlah penduduk, semakin besar permintaan terhadap suatu barang dan jasa. Penduduk yang dimaksud adalah konsumen yang potensial dalam mengkonsumsi barang. Hubungan variabel jumlah barang yang diminta dengan konsumen potensial adalah positif.

d. Pendapatan

Pendapatan masyarakat mencerminkan daya beli masyarakat. Tinggi atau rendahnya pendapatan masyarakat akan mempengharui kualitas maupun kuantitas permintaan (Rahardja dan Manurung, 2001). Rumah tangga yang memiliki pendapatan lebih tinggi sanggup membeli banyak barang sebaliknya rumah tangga yang memiliki pendapatan rendah cendrung mengurangi permintaan terhadap suatu barang.

\section{e. Selera}

Selera dan juga pilihan terhadap suatu barang merupakan variabel yang mempengharui besar kecilnya permintaan. Karena apabila perubahan selera konsumen maka akan terjadi dampak terhadap permintaan suatu komoditas (Sukirno, 2013). Selara dan pilihan konsumen terhadap suatu barang bukan saja dipengharui oleh struktur umur konsumen, tetapi juga dipengaharui faktor adat dan kebiasaan setempat dan tingkat pendidikan.

\section{Hukum Permintaan}

Penjelasan mengenai perilaku konsumen yang paling sederhana didapati dalam hukum permintaan (The Law of demand) yang menyatakan bahwa bila harga suatu barang naik cateris paribus, maka jumlah yang diminta konsumen akan barang tersebut turun dan sebaliknya jika harga barang tersebut turun maka jumlah barang yang diminta oleh konsumen akan naik dengan syarat faktorfaktor lain dianggap cateris paribus. Cateris paribus berarti bahwa semua faktor-faktor lain yang mempengaruhi jumlah barang yang diminta dianggap tidak berubah.

\section{Kurva Permintaan}

Kurva Permintaan dapat didefinisikan sebagai: "Suatu kurva yang menggambarkan sifat hubungan antara harga suatu barang tertentu dengan jumlah barang tersebut yang diminta para pembeli." Kurva permintaan mempunyai slope negatif dari kiri atas ke kanan bawah, dimana jika terjadi penurunan harga akan menambah jumlah komoditi yang diminta (Nicholson, 2001). Kemiringan (Slope) dari suatu kurva permintaan menggambarkan besarnya perubahan jumla barang yang diminta sebagai akibat perubahan harga. Semakin landai suatu kurva permintaan semakin besar perubahan jumlah barang yang diminta jika harga naik atau turun, cateris peribus.

\section{Elastisitas Permintaan}

Elastisitas menggambarkan reaksi derajat kepekaan fungsi terhadap perubahan yang terjadi pada variabel-variabel yang mempengaruhinya. Besar angka elastisitas juga mempengaruhi arah kurva permintaan (Boediono, 2000). Elastisitas permintaan juga dapat diartikan sampai dimana responsifnya perubahan permintaan sebagai akibat dari perubahan faktor-faktor penentu permintaan (Sukirno, 2003). 


\section{Pendapatan}

Pendapatan seseorang dapat didefinisikan sebagai banyaknya penerimaan yang dinilai dengan satuan mata uang yang dapat dihasilkan seseorang atau bangsa dalam periode tertentu (Mahyu dani, 2013). Sukirno (2005) menulis bahwa pendapatan merupakan salah satu faktor terpenting yang mempengaruhi sebuah permintaan, pada hakikatnya merupakan hipotesis yang menyatakan bahwa makin tinggi pendapatan maka makin banyak permintaan terhadap barang tersebut. Sebaliknya, makin rendah pendapatan maka makin sedikit permintaan terhadap barang tersebut. Hubungan yang wujud merupakan hubungan berbanding lurus, sehingga jika terdapat kenaikan pendapatan, maka hal ini mengakibatkan permintaan listrik akan lebih baik bahkan meningkat. Besar kecilnya pendapatan seseorang berpengaruh kepada kemampuan daya beli seseorang tersebut, termasuk dalam permintaan listrik. Semakin tinggi pendapatan semakin beragam pula keinginan konsumen.

\section{Harga/tarif listrik}

Menurut Peraturan Menteri Energi dan Sumber Daya Mineral Republik Indonesia, Nomor 41 Tahun 2017, Pasal 1 menyatakan bahwa: "Tarif Tenaga Listrik adalah tarif tenaga listrik untuk konsumen yang disediakan oleh PT Perusahaan Listrik Negara (Persero)". Tarif dasar listrik atau biasa disingkat TDL, adalah tarif (biaya yang harus dibayar) yang boleh dikenakan oleh pemerintah untuk para pelanggan PLN. PLN adalah satu-satunya perusahaan yang boleh menjual listrik secara langsungm kepada masyarakat Indonesia. maka TDL bisa dibilang adalah tarif untuk penggunaan listrik di Indonesi. Sedangkan menurut Abdul Kadir (2005), tarif dasar listrik secara umum dapat diartikan sebagai daftar harga penjualan tenaga listrik yang ditetapkan oleh perusahaan listrik untuk para langganan atau konsumen energi listrik. Penentuan tarif dasar listrik didasarkan pada beberapa faktor seperti biaya modal, perawatan dan perbaikan, upah tenaga kerja, biaya bahan bakar dan lain sebagainya yang berkaitan dengan proses pembangkitan energi listrik tersebut sampai digunakan oleh konsumen. Biaya-biaya tersebut tidak semuanya ditanggung oleh PLN tetapi juga dilimpahkan kepada konsumen melalui tarif dasar listrik. Penentuan tarif yang tidak bijaksana dapat berakibat buruk terhadap perkembangan perusahaan, misalnya tarif yang tinggi terhadap biaya instansi dapat membuat langganan berkurang atau tarif yang rendah akan menyebabkan pemborosan energi listrik yang dapat mengakibatkan perusahaan mengalami kerugian.

Hal ini selaras dengan hukum permintaan dimana menurut Sukirno (2005) menulis bahwa hukum permintaan pada hakikatnya merupakan hipotesis yang menyatakan bahwa makin rendah harga suatu barang maka makin banyak permintaan terhadap barang tersebut. Sebaliknya, makin tinggi harga suatu barang maka makin sedikit permintaan terhadap barang tersebut. Hubungan yang terbalik, sehingga jika terdapat kenaikan harga, maka hal ini mengakibatkan permintaan listrik menurun.

\section{Jumlah Anggota Keluarga}

Keluarga adalah kelompok orang yang mendiami sebagian atau seluruh bangunan fisik dan biayanya tingga biasanya yang tinggal bersama terdiri dari suami, istri, anak, serta orang lain yang ikut bersama mereka (Lipsey dan steiner, 2003 ). Macam-macam keluarga menurut Kolter (2001) sebagai berikut :

1. Keluarga inti menunjukan lingkup keluarga yang meliputi ayah, ibu dan anak-anak yang hidup dalam satu rumah.

2. Keluarga besar adalah keluarga inti ditambah orang-orang yang mempuyai ikatan saudara keluarga tersebut.

Menurut Nilagupta, (2013) jumlah anggota keluarga atau jumlah orang yang tinggal dalam rumah tangga pada suatu daerah tertentu merupakan variabel penting dalam menentukan permintaan 
energi listrik rumah tangga. Karena dalam memenuhi kebutuhan hidup rumah tangga seseorang tidak hanya memperhatikan tingkat pendapatan yang diterima, tetapi juga memperhatikan jumlah anggota keluarga yang ditanggung, semakin bersar jumlah anggota keluarga yang ditanggung maka semakin besar pula pengeluaran untuk memenuhi kebutuhan rumah tangga tersebut, sehingga akan mempengaruhi pola permintaan listrik rumah tangga. Karena setiap anggota keluarga memiliki kebutuhannya tersendiri terhadap penggunaan alat-alat yang menggunakan listrik.

\section{METODE PENELITIAN}

Jenis penelitian ini menggunakan metode pendekatan deskriptif kuantitatif, yaitu digunakan untuk menguji suatu teori, untuk menyajikan suatu fakta atau mendiskripsikan statistik, untuk menunjukkan hubungan antar variabel. Adapun variabel dalam penelitian ini yaitu variabel independen (pendapatan, harga/ tarif listrik dan Jumlah anggota keluarga) terhadap variabel dependen (permintaan energi listrik rumah tangga).

Desain penelitian ini merupakan penelitian survei, yaitu penelitian yang menggunakan kuesioner sebagai alat pengumpulan data yang pokok. Dimana populasi dalam penelitian ini adalah semua pelanggan rumah tangga yang menggunakan energi listrik sebanyak 121.681 pelanggan. Dan berdasarkan hasi perhitungan dari rumus slovin maka jumlah sampel yang diambil dalam penelitian ini sebanyak 100 sampel rumah tangga di Kota Bengkulu.

Dimana 100 sampel tersebut diambil dari jumlah populasi yang ada di sembilan Kecamatan Kota Bengkulu yang kemudian dari masing-masing kesembilan Kecamatan tersebut memiliki jumlah pengambilan sampel yang berbeda-beda sesuai dengan hasil perhitungan secara proportional sampling. Dan sampel yang dipilih dalam penelitian ini merupakan rumah tangga yang menggunakan listrik dengan daya dari 450 Volt Amper, 900 Volt Amper, R1M 900 Volt Amper, 1.300 Volt Amper, 2.200 Volt Amper, sampai 3.500 Volt Amper.

Dalam menganalisis faktor-faktor yang mempengaruhi permintaan listrik maka digunakan metode analisis yatitu model regresi linear berganda. Menurut Sugiyono (2014) regresi linear berganda yaitu untuk mengetahui seberapa besar pengaruh variabel $\mathrm{X} 1, \mathrm{X} 2, \mathrm{X} 3$ terhadap variabel $\mathrm{Y}$ dengan formulasi sebagai berikut :

Dimana :

$$
\mathrm{Y}=\beta 0+\beta 1 \mathrm{X1}+\beta 2 \mathrm{X2}+\beta 3 \mathrm{X3}+\mu
$$

$\begin{array}{ll}\mathrm{Y} & =\text { Permintaan Listrik } \\ \beta 0 & =\text { Konstanta } \\ \beta 1, \beta 2, \beta 3 & =\text { Koefisien regresi } \\ \mathrm{X} 1 & =\text { Pendapatan } \\ \mathrm{X} 2 & =\text { Tarif / Harga Listrik } \\ \mathrm{X} 3 & =\text { Jumlah Anggota keluarga } \\ \mu & =\text { Variabel Pengganggu }\end{array}$

Untuk memastikan bahwa hasil penelitian yang dilakukan valid dengan data yang digunakan secara teori adalah tidak bias, konsisten dan penaksiran koefisienan regresinya efisien maka peneliti menggunakan uji asumsi klasik. Dalam penelitian ini uji asumsi klasi yang dilakukan adalah pengujian uji multikolinearitas, uji heteroskedestisitas, uji autokorelasi dan uji normalitas.

\section{Uji Multikolinearitas}

Uji multikolinearitas adalah untuk melihat hubungan linear antar variabel independen. Dalam asumsi regresi linear klasik, antar variabel independent tidak diijinkan uantuk saling berkolerasi. Terdapatnya multikolinearitas akan menyebabkan besarnya varian koefisien regresi yang 
berdampak pada lebarnya interval kepercayaan terhadap variabel bebas yang digunakan. Salah satu cara untuk menganalisis ada atau tidaknya masalah multikolinearitas dalam persamaan regresi adalah dengan cara melihat nilai VIF dari masing-masing variabel independen, apabila nilai tersebut tidak melebihi 10 maka tidak terdapat multikolinearitas. Sebaliknya jika nilai VIF variabel independen melebihi 10 diduga mengandung unsur multikolinearitas.

\section{Uji Heteroskedasitas}

Uji heteroskedastisitas bertujuan untuk menguji apakah dalam model regresi terdapat ketidaksamaan variance dari residual satu pengamatan ke pengamatan lainnya. Apabila variance dari residual satu pengamatan ke pengamatan lain tetap, maka hal tersebut disebut homoskedastisitas dan jika berbeda disebut heteroskedastisitas. Suatu model yang baik adalah model yang terdapat homoskedastisitas atau tidak terjadi heteroskedastisitas.

\section{Uji Autokorelasi}

Uji autokorelasi merupakan korelasi antar variabel gangguan satu observasi dengan gangguan observasi lain (Widarjono, 2010). Uji autokorelasi bertujuan menguji apakah dalam model regresi liner ada korelasi antara kesalahan pengganggu karena autokorelasi terjadi apabila nilai variabel masa lalu memiliki pengaruh terhadap nilai variabel masa sekarang, atau masa depan. Autokorelasi akan menghasilkan estimasi yang terlalu rendah untuk nilai variasi $\mu \mathrm{i}$,sehingga $\mathrm{R}^{2}$ menjadi terlalu tinggi dan juga signifikasi uji t dan uji $\mathrm{F}$ menjadi tidak valid atau menyesatkan.

\section{Uji Normalitas}

Uji normalitas bertujuan untuk menguji apakah dalam sebuah model regresi, variabel dependen dan variabel independen ataupun keduanya mempunyai distribusi normal atau tidak (Ghozali, 2013). Model regresi yang baik adalah distribusi data normal atau mendekati normal.Sedangkan untuk melihat pengaruh signifikan antara variabel independen terhadap variabel dependen maka dilakukan uji statistik yang dimana pengujian hipotesisnya dilakukan dengan menggunakan tahapan-tahapan sebagai berikut :

\section{Uji F}

Uji $\mathrm{F}$ merupakan uji secara simultan atau serempak signifikan pengaruh perubahan variabel independen terhadap variabel dependen (Ghozali, 2013). Artinya parameter X1, X2 dan X3 secara bersamaan diuji apakah memiliki signifikansi atau tidak terhadap permintaan energi listrik (Y) sebagai variabel terikat

\section{Uji t}

Uji-t adalah digunakan bertujuan untuk menunjukkan apakah masing-masing variabel independen secara parsial berpengaruh nyata atau tidal terhadap variabel dependen (Ghozali, 2013). Untuk memastikan bahwa hasil penelitian adalah valid dengan data yang digunakan secara teori adalah tidak bias, konsisten dan penaksiran koefisienan regresinya efisien maka digunakan uji asumsi klasik. Dimana Dalam penelitian ini uji asumsi klasi yang dilakukan adalah pengujian multikolinearitas, autokorelasi normalitas dan heteroskedestisitas.

\section{Koefisien determinasi $\left(\mathbf{R}^{2}\right)$}

Koefisien determinasi $\left(\mathrm{R}^{2}\right)$ merupakan indikator statistik yang digunakan untuk mengukur seberapa besar presentase sumbangan variabel bebas secara serentak terhadap variabel terikat (Gujarati, 2003). 


\section{HASIL DAN PEMBAHASAN}

Adapun karakteristik responden dalam penelitian ini dapat dilihat dari beberapa variabel yaitu permintaan listrik, pendapatan, harga/ tarif listrik dan jumlah anggota keluarga

Tabel 3 Jumlah Responden Menurut Tingkat Pendapatan

\begin{tabular}{lcl}
\hline Pendapatan & Jumlah Responden & $(\%)$ \\
\hline $600.000-999.000$ & 7 & 7 \\
$1.000 .000-2.999 .000$ & 63 & 63 \\
$3.000 .000-4.999 .000$ & 23 & 23 \\
$5.000 .000-6.999 .000$ & 4 & 4 \\
$7.000 .000-8.500 .000$ & 3 & 3 \\
\hline Jumlah & 100 & 100 \\
\hline
\end{tabular}

Sumber : Hasil Penelitian, 2019.

Dari Tabel 3 dapat diketahui bahwa pendapatan tertinggi adalah Rp 8.500.000 dengan jumlah responden 3 pelanggan dan yang terendah adalah Rp 600.000 dengan jumlah responden 7 pelanggan. Sedangkan pelanggan yang mendapatkan pendapatan 1.000.000 - 2.900.000 sebanyak 63 responden yang dimana menunjukan bahwa pendapatan Kota Bengkulu masih tergolong rendah. Kemudian disusul dengan pendapata responden antar Rp 600.000 - Rp 999.000 sebanyak 7 responden atau sebesar $7 \%$, dan pendapatan Rp 3.000.000 - Rp 4.999 .000 sebanyak 23 responden atau sebesar $23 \%$, pendapatan Rp 5.000.000 - 6.999.000 sebanyak 4 responden atau sebesar $4 \%$ dan pendapatan responden yang terkecil yaitu Rp 7.000.000 - 8.500.000 sebanyak 3 responden atau sebesar $3 \%$ dari keseluruhan responden.

Tabel 4 Jumlah Responden Menurut Harga/tarif Listrik

\begin{tabular}{llc}
\hline Harga/tarif Listrik & Jumlah Responden & $(\%)$ \\
\hline 415 & 12 & 12 \\
586 & 16 & 16 \\
1.352 & 30 & 30 \\
1.467 & 42 & 42 \\
\hline Jumlah & 100 & 100 \\
\hline
\end{tabular}

Sumber : Hasil Penelitian, 2019.

Dari Tabel 4 diatas diperoleh bahwa harga/tarif listrik yang tertinggi adalah $\mathrm{Rp} 1.467$ sebesar 42 reseponden atau $42 \%$ dari keseluruhan responden dan harga/tarif listrik yang terkecil adalah Rp 415 sebesar 12 responden atau $12 \%$ dari keseluruhan responden . maka ini artinya bahwa setiap harga/tarif listrik yang dikenakan oleh rumah tangga di Kota Bengkulu tergolong tinggi dalam setiap pemakaian listrik perkwhnya. Kemudian diikuti harga/tarif listrik Rp 586 sebanyak 16 responden atau sebesar 16\%, dan harga/tarif listrik Rp 1.352 sebanyak 30 responden atau $30 \%$ dari keseluruhan responden.

Tabel 5 Jumlah Responden Menurut Jumlah Anggota Keluarga

\begin{tabular}{ccc}
\hline Jumlah Anggota Keluarga & Jumlah Responden & $(\%)$ \\
\hline $2-3$ & 26 & 25 \\
$4-5$ & 52 & 53 \\
$6-7$ & 21 & 21 \\
8 & 1 & 1 \\
\hline Jumlah & 100 & 100 \\
\hline
\end{tabular}

Sumber: Hasil Penelitian, 2019. 
Dari Tabel 5 diatas diketahui bahwa jumah anggota keluarga yang tertinggi adalah 8 orang dan yang terendah adalah 2 orang, sedangkan jumlah rata-rata anggota keluarga adalah 4 sampai 5 orang, yaitu sebanyak 53 responden atau sebesar $53 \%$ dari keseluruhan responden. Hal ini dapat menunjukkan bahwa rata-rata responden telah mengikuti program keluarga berencana. Dan jumlah anggota keluarga 2 sampai 3 orang sebanyak 25 responden atau sebesar $25 \%$, kemudian diikuti jumlah anggota 6 sampai 7 orang sebanyak 21 responden atau sebanyak $21 \%$ dan jumlah anggota keluarga yang paling sedikit respondennya adalah 8 orang sebanyak 1 responden atau sebesar $1 \%$ dari keseluruhan responden.

Tabel 6 Jumlah Responden Menurut Jumlah Permintaan Listrik (kWh)

\begin{tabular}{ccc}
\hline Jumlah Permintaan Listrik & Jumlah Responden & $(\%)$ \\
\cline { 2 - 3 } $48-99$ & 6 & 6 \\
\hline $100-199$ & 32 & 32 \\
\hline $200-299$ & 36 & 36 \\
\hline $300-399$ & 20 & 20 \\
\hline $400-499$ & 2 & 2 \\
\hline $500-579$ & 4 & 100 \\
\hline Jumlah & 100 &
\end{tabular}

Sumber : Hasil Penelitian, 2019.

Dari Tabel 6 bahwa jumlah permintaan listrik tertinggi adalah 579 kwh sedangkan permintaan listrik yang terkecil adalah $48 \mathrm{kwh}$ dan rata-ratan permintaan listrik adalah $242 \mathrm{kwh}$. Tetapi sebagaian besar dari responden permintaan listrik yang terbanyak yaitu antara $200 \mathrm{kwh}$ sampai 299 kwh setiap bulannya sebanyak 36 responden atau sebesar $36 \%$ dari keseluruhan responden maka hal ini menunjukkan bahwa tingkat pemakaian/ permintaan listrik rumah tangga yang ada di Kota Bengkulu dapat dikatakan cukup tergolong tinggi. Kemudian diikuti permintaan listrik antara 48 kwh sampai 99 kwh sebanyak 6 responden atau $6 \%$ dari keseluruhan reseponden dan permintaan listrik $100 \mathrm{kwh}$ samapai $199 \mathrm{kwh}$ sebanyak 32 responden. Berikutnya permintaan listrik antara 300 kwh sampai 399 kwh sebanyak 20 responden dan permintaan listrik responden antara $500 \mathrm{kwh}$ sampai 579 kwh sebanyak 4 responden atau sebesar $4 \%$ dari keseluruhan responden.

\section{Hasil Uji Asumsi Klasik}

Tabel 7 Hasil Uji Multikolinearitas

\begin{tabular}{cccc}
\hline & Coefficient & Uncentered & Centered \\
Variable & Variance & VIF & VIF \\
\hline C & 1312.866 & 23.03373 & NA \\
X3 & 37.63284 & 13.90494 & 1.005962 \\
X2 & 0.000425 & 11.24066 & 1.240887 \\
X1 & $3.53 E-11$ & 4.748842 & 1.238926 \\
\hline
\end{tabular}

Sumber : Hasil Pengolahan Data, 2019

Berdasarkan hasil dari Tabel 7 menunjukkan bahwa setiap masing-masing variabel independen memiliki nilai VIF yang lebih kecil dari 10 maka dapat disimpulkan bahwa tidak terdapat atau tidak memiliki masalah multikolinearitas.

Tabel 8 Hasil Uji Heteroskedestisitas

\begin{tabular}{llll}
\hline F-statistic & 0.582615 & Prob. F(3,96) & 0.6278 \\
Obs*R-squared & 1.788116 & Prob. Chi-Square(3) & 0.6175 \\
Scaled explained SS & 1.829380 & Prob. Chi-Square(3) & 0.6086 \\
\hline
\end{tabular}


Sumber : Hasil Pengolahan Data, 2019

Dari Table 8 diatas menjelaskan bahwa nilai prob. Chi-Square sebesar 0.6175 . hal ini menunjukan bahwa nilai prob. Chi-Square lebih besar dari alpha 0,05 sehingga dapat disimpulkan bahwa tidak terdapat atau tidak memiliki masalah heteroskedastisitas.

Tabel 9 Hasil Uji Autokorelasi

\begin{tabular}{lrll}
\hline F-statistic & 0.125709 & Prob. F(1,95) & 0.8820 \\
Obs*R-squared & 0.266753 & Prob. Chi-Square (1) & 0.8751 \\
\hline
\end{tabular}

Sumber : Hasil Pengolahan Data, 2019

Pada Tabel 9 dapat dilihat bahwa pada penelitian ini diperoleh nilai statistik $O b s * R$-squared sebesar 0.266753 dengan Probability-value sebesar 0,8751. Karena Probability-value $O b s * R$ squared $0.8751>0,05$ maka H0 diterima, artinya pada penelitian ini tidak memiliki masalah autokorelasi.

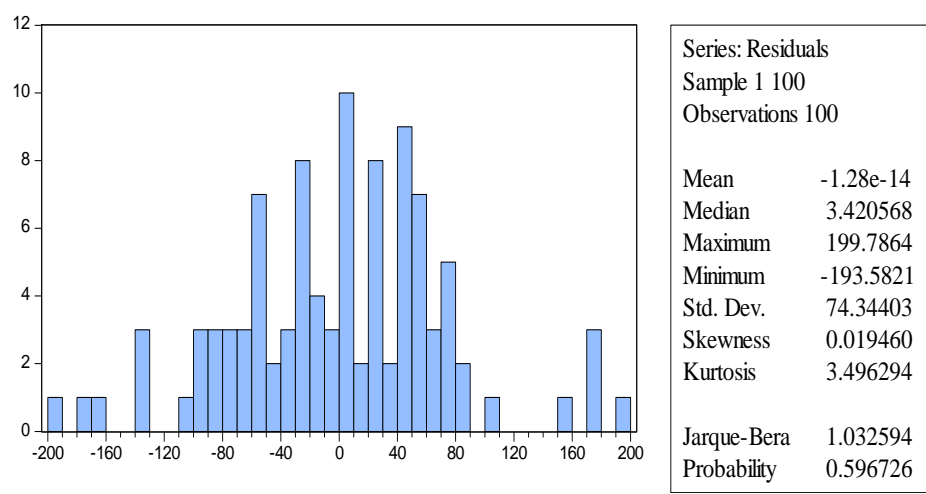

\section{Gambar 1 Hasil Uji Normalitas}

Dari Gambar 1 dapat diketahui bahwa nilai probability dari Jarque-Bera (JB) sebesar 0,596726 lebih besar dari 0,05 atau 5\%, maka hal ini menunjukkan bahwa variabel pendapatan, harga/tarif listrik dan jumlah anggota keluarga terhadap variabel permintaan energi listrik rumah tangga berdistribusi normal.

Berdasarkan pengolahan data dengan menggunakan program eviews 9, diperoleh hasil estimasi regresi linier berganda yang dapat dilihat pada rabel 4.8 sebagai berikut :

Tabel 10 Hasil Estimasi Regresi

\begin{tabular}{cclcc}
\hline \multicolumn{1}{c}{ Variable } & Coefficient & Std. Error & t-Statistic & Prob. \\
\hline \multicolumn{1}{c}{ C } & 28.99806 & 36.23350 & 0.800311 & 0.4255 \\
X1 & $4.82 \mathrm{E}-05$ & $5.94 \mathrm{E}-06$ & 8.113692 & 0.0000 \\
X2 & -0.046800 & 0.020609 & -2.270802 & 0.0254 \\
X3 & 10.16695 & 6.134561 & 1.995323 & 0.0470 \\
\hline R-s Quared & 0.536548 & Mean dependent var & 242.9100 \\
Adjusted R-squared & 0.522065 & S.D. dependent var & 109.2053 \\
S.E. of regression & 75.49672 & Akaike info criterion & 11.52523 \\
Sum squared resid & 547176.5 & Schwarz criterion & 11.62944 \\
Log likelihood & -572.2617 & Hannan-Quinn criter & 11.56741 \\
F-statistic & 37.04707 & Durbin-Watson stat & 1.848641 \\
& & &
\end{tabular}


Sumber: Hasil Pengolahan Data, 2019.

\section{Uji F}

Dari hasil estimasi pada Tabel 4.8 dapat dilihat bahwa nilai Fhitung / Fstatistik sebesar 37,047 dan nilai Ftabel sebesar $(0,05: 3: 96)=2,70$ dengan menggunakan tingkat signifikan $\alpha=0,05$. Karena nilai Fhitung > Ftabel $(37,047>2,70)$ maka dapat disimpulkan bahwa pengujian hipotesis diatas menolak $\mathrm{H} 0$ dan menerima $\mathrm{H} 1$, yang artinya bahwa variabel pendapatan, tarif/harga listrik dan jumlah anggota keluarga secara bersama-sama berpengaruh signifikan terhadap variabel permintaan energi listrik.

\section{Uji t}

a. Variabel Pendapatan

Dari hasil regresi diketahui bahwa nilai thitung sebesar 8,113 sedangkan nilai ttabel dengan $\alpha=5 \%$ dengan derajat kebebasan 96 sehingga di peroleh ttabel $(0,05 / 2 ; 96)=1,984$. Karena thitung > ttabel $(8,113>1,984)$ maka $\mathrm{H} 0$ ditolak dan $\mathrm{H} 1$ diterima, yang bearti bahwa variabel pendapatan berpengaruh signifikan terhadap variabel permintaan energi listrik.

b. Variabel Harga/tarif Listrik

Dari hasil regresi diketahui bahwa nilai thitung sebesar -2,270 sedangkan nilai ttabel dengan $\alpha=5 \%$ dengan derajat kebebasan 96 sehingga di peroleh ttabel $(0,05 / 2 ; 96)=1,984$. Karena thitung > ttabel $(2,270>1,984)$ maka $\mathrm{H} 0$ ditolak dan $\mathrm{H} 1$ diterima yang bearti bahwa variabel Harga/tarif Listrik berpengaruh signifikan terhadap variabel permintaan energi listrik.

c. Variabel Jumlah Anggota Keluarga

Dari hasil regresi diketahui bahwa nilai thitung sebesar 1,995 sedangkan nilai ttabel dengan $\alpha=5 \%$ dengan derajat kebebasan 96 sehingga di peroleh ttabel $(0,05 / 2 ; 96)=1,984$. Karena thitung > ttabel $(1,995>1,984)$ maka H0 ditolak dan H1 diterima yang bearti bahwa variabel jumlah anggota keluarga berpengaruh signifikan terhadap variabel permintaan energi listrik.

\section{Koefisien Determinasi $\left(\mathbf{R}^{2}\right)$}

Dari hasil regresi, nilai koefisien determinasi $\left(\mathrm{R}^{2}\right)$ sebesar 0,536 . Hal ini menunjukkan bahwa presentase sumbangan pengaruh variabel independen (pendapatan, harga/taif listrik, jumlah anggota keluarga) terhadap variabel dependen (permintaan energi listrik) sebesar 53,6 \%. Sementara sisannya sebesar $46,4 \%$ dijelaskan oleh faktor-faktor lain diluar penelitian ini.

\section{HASIL DAN PEMBAHASAN}

Dari hasil pengolahan data dengan menggunakan alat analisis regresi linier berganda empat variabel, maka didapat persamaan regresi sebagai berikut :

$\mathrm{Y}=28,998+0,0000482 \mathrm{X} 1-0,0468 \mathrm{X} 2+10,166 \mathrm{X} 3$

Berdasarkan hasil estimasi data dalam model regresi diatas terdapat nilai konstanta sebesar 28,998 bertanda positif artinya jika tidak ada pendapatan, tarif/harga listrik dan jumlah anggota keluarga maka jumlah permintaan listrik masyarakat naik sebesar 28,998 kwh. 


\section{Pengaruh Pendapatan Terhadap Permintaan Listrik}

Berdasarkan hasil perhitungan menunjukkan bahwa variabel pendapatan (X1) memiliki nilai thitung sebesar 8,113 yang dimana lebih besar dari nilai ttabel sebesar 1,984 maka H0 ditolak dan H1 diterima, artinya bahwa variabel pendapatan berpengaruh secara signifikan terhadap variabel permintaan listrik rumah tangga di Kota Bengkulu, sehingga hipotesis pertama diterima. Selain itu variabel pendapatan juga bertanda positif terhadap variabel permintaan listrik dengan nilai koefisiennya sebesar 0,0000482, yang menunjukkan bahwa setiap kenaikan pendapatan sebesar 1 rupiah maka akan meningkatkan permintaan energi listrik rumah tangga sebesar 0,0000482 $\mathrm{Kwh}$, dan jika pendapatan terus meningkat sebesar 10.000 rupiah maka permintaan energi listrik juga meningkat sebesar 0,482 Kwh dengan asumsi (Ceteris Paribus) atau variabel lainnya dianggap tetap.

Hal ini sesuai dengan teori permintaan yang menyatakan bahwasanya faktor yang paling penting dalam permintaan barang atau jasa adalah pendapatan karena pendapatan merupakan penentu besar kecilnya permintaan (Sukirno, 2013). Dimana semakin besar pendapatan yang diterima suatu kepala rumah tangga maka semakin tinggi juga permintaan energi listrik yang digunakan oleh rumah tangga tersebut begitu juga dengan sebaliknya semakin kecil pendapatan yang diterima maka semakin kecil juga permintaan energi listrik yang digunakan tersebut. Hal ini disebabkan karena pendapatan mencerminkan kemampuan daya beli masyarakat, sehingga apabila pendapatan suatu rumah tanga meningkat maka kemampuan daya belinya terhadap kebutuhan barang-barang yang menggunakan tenaga listrik juga akan mengalami peningkatan. Sehingga menyebabkan pemakaian/ permintaan listrik dalam rumah tangga tersebut juga meningkat.

Hasil penelitian ini sejalan dengan hasil penelitian yang dilakukan oleh Fajrah (2018) mengenai faktor-faktor yang mempengaruhi permintaan jumlah daya listrik rumah tangga di Kota Banda Aceh, mengungkapkan bahwa variabel pendapatan memiliki pengaruh signifikan terhadap permintaan listrik. Hal ini juga dudukung oleh penelitian lainya Bacthiar (2013), Erikson (2011), Nababan (2015), dimana hasil penelitiannya menunjukkan bahwa variabel pendapatan mempuyai pengaruh positif dan signifikan terhadap permintaan energi listrik rumah tangga.

\section{Pengaruh Harga/tarif Listrik Terhadap Permintaan Listrik}

Berdasarkan hasil perhitungan menunjukkan bahwa variabel harga/ tarif listrik (X2) memiliki nilai thitung sebesar 2,270 yang dimana lebih besar dari nilai ttabel sebesar 1,984 maka H0 ditolak dan H1 diterima, artinya bahwa variabel harga/ tarif listrik berpengaruh secara signifikan terhadap variabel permintaan energi listrik rumah tangga yang ada di Kota Bengkulu, sehingga hipotesis kedua dapat diterima. Variabel harga/ tarif juga memiliki hubungan bertanda negatif terhadap variabel permintaan listrik dengan nilai koefisiennya sebesar -0,0468 yang memberikan makna bahwa setiap penambahan harga/ tarif listrik sebesar 1 rupiah akan menurunkan permintaan energi listrik rumah tangga sebesar 0,0468 kwh dengan asumsi (Ceteris Paribus) atau variabel lainnya dianggap tetap.

Hal ini sesuai dengan teori permintaan menurut Arsyad (2001) menyatakan bahwa hubungan antara harga dengan kuantitas yang diminta adalah berbanding terbalik (negatif). Jika harga naik, kuantitas yang diminta akan turun dan sebaliknya jika harga turun maka kuantitas yang diminta akan naik. Hal ini dikarenakan tingginya harga/ tarif listrik yang dikenakan pada pelanggan akan menyebabkan pengeluaran yang harus dibayar oleh rumah tangga akan lebih mahal dan dapat mengurangi daya beli sehingga pelanggan rumah tangga akan mengurangi pemakaian pada energi listrik tersebut.

Hasil penelitian ini sama dengan hasil penelitian terdahulu yang telah dilakukan oleh Erikson (2011), mengenai analisis faktor-faktro yang mempengaruhi permintaan konsumen listrik pada 
rumah tangga sederhana (studi kasus pada rumah tangga pelanggan 450 VA dan 900 VA di Desa Hutatoruan 1, Tarutung, Kabupaten Tapanuli Utara).

Dari hasil penelitiannya menunjukkan bahwa variabel harga/tarif listrik mempuyai pengaruh negatif dan signifikan terhadap permintaan energi listrik rumah tangga. Hal ini menurut Erikson (2011) harga listrik merupakan sebagai suatu komoditi yang diasumsikan sebagai barang normal. Sehingga adanya kenaikan harga listrik akan mengurangi permintaan listrik itu sendiri yakni rumah tangga konsumen sudah tentu akan melakukan penghematan sehingga pemakaian listrik akan lebih efisien.

\section{Pengaruh Jumlah Anggota Keluarga Terhadap Permintaan Listrik}

Berdasarkan hasil perhitungan menunjukkan bahwa variabel jumlah anggota keluarga (X3) memiliki nilai thitung sebesar 1,995 yang dimana lebih besar dari nilai ttabel sebesar 1,984 maka H0 ditolak dan $\mathrm{H} 1$ diterima, artinya bahwa variabel jumlah anggota keluarga berpengaruh secara signifikan terhadap variabel permintaan energi listrik rumah tangga yang ada di Kota Bengkulu, sehingga hipotesis ketiga dapat diterima. Variabel jumlah anggota keluarga juga memiliki hubungan yang bertanda positif terhadap variabel permintaan listrik dengan nilai koefisiennya sebesar 10,16695 memberikan makna bahwa setiap penambahan jumlah anggota keluarga sebesar 1 orang akan meningkatkan permintaan energi listrik rumah tangga sebesar 10,16695 kwh dengan asumsi (Ceteris Paribus) atau variabel lainnya dianggap tetap.

Hal ini sesuai dengan teori ekonomi menurut Nilagupta (2013) jumlah anggota keluarga atau jumlah orang yang tinggal dalam rumah tangga pada suatu daerah tertentu merupakan variabel penting dalam menentukan permintaan energi listrik rumah tangga. Karena dalam memenuhi kebutuhan hidup rumah tangga seseorang tidak hanya memperhatikan tingkat pendapatan yang diterima saja tetapi memperhatikan juga jumlah anggota keluarga yang ditanggung, semakin besar jumlah anggota keluarga yang ditanggung semakin besar pula pengeluaran untuk memenuhi kebutuhan rumah tangga tersebut.

Setiap terjadinya pertambaha jumlah anggota keluarga dalam suatu rumah tangga akan menyebabkan permintaan energi listrik rumah tangga tersebut akan meningkat dan sebaliknya semakin berkurangnya jumlah anggota keluarga maka permintaan energi listrik akan pada rumah tangga juga rendah. karena dari setiap individu pasti membutuhkan energi listrik atau alat-alat yang menggunakan tenaga listrik dalam membantu kegiatan sehari-hari mereka, apalagi dizaman sekarang ini, semua peralatan rumah tangga hampir semuanya menggunakan listrik. sehingga penambahan jumlah anggota keluarga memberikan dampak pada semakin besarnya energi listrik yang dibutuhkan dan pada akhirnya akan mempegaruhi seerta dapat meningkatkan permintaan listrik rumah tangga yang ada di Kota Bengkulu.

Hal ini sesuai dengan Hasil studi Reiss \& White (2001) menyimpulkan bahwa koefisien variabel ukuran (jumlah) anggota keluarga bisa positif bisa negatif. Alasannya adalah besarnya konsumsi listrik tergantung pada banyaknya alat listrik yang digunakan. Namun, dia juga sependapat bahwa jika ukuran keluarga semakin besar ada kecenderungan lebih banyak menggunakan energi listrik.

Hasil penelitian ini juga sejalan dengan hasil penelitian terdahulu yang telah dilakukan oleh Nababan (2008) mengenai permintaan energi listrik rumah tangga (Studi kasus pada penggunaan kelompok rumah tangga listrik PT PLN (persero) di Kota Medan. Dimana hasil penelitiannya menunjukkan bahwa variabel jumlah anggota keluarga mempuyai pengaruh positif dan signifikan terhadap permintaan energi listrik pada rumah tangga. Hal ini juga didukung dengan penelitian lainnya, Bacthiar (2013), Erikson (2011), Kusumaningtyas (2017) dan Erfani (2008) bahwa variabel jumlah anggota keluarga mempuyai pengaruh positif dan signifikan terhadap permintaan energi listrik. 


\section{KESIMPULAN DAN SARAN}

Berdasarkan tujuan penelitian yang telah dipaparkan yaitu untuk mengetahui pendapatan, harga/ tarif listrik dan jumlah anggota keluarga berpengaruh terhadap permintaan listrik dan juga pada hasil penelitian serta pembahasan yang telah diuraikan sebelumnya, maka dapat ditarik beberapa kesimpulan bahwa : variabel independen yaitu pendapatan, harga/ tarif listrik dan jumlah anggota keluarga baik secara parsial maupun secara simultan berpengaruh secara signifikan terhadap variabel dependen yaitu permintaan energi listrik pada rumah tangga di Kota Bengkulu.

Kemudian rekomendasi untuk penelitian selanjutnya dapat diharapkan bisa lebih menyempurnakan penelitian ini dengan menambah alat ukur variabel lainnya seperti jumlah peralatan listrik, luas bangunan, tingkat pendidikan, biaya pengeluran energi listrik dan variabel lainnya yang juga dapat mempengaruhi permintaan listrik serta diharapkan memperpanjang cakupan waktu dan memperluas ruang lingkup penelitian untuk hasil yang lebih maksimal.

\section{DAFTAR PUSTAKA}

Adiningsih, Sri. 2004. Ekonomi Mikro. Yogyakarta: BPFE UGM.

Arsyad, Lincolin. 2001. Ekonomi Mikro, Edisi 1. Yogyakarta: Penerbit BPFE.

Azheri, Mochtar. 2007. Pengantar Ilmu Ekonomi. Bandung: Budi Mulya.

Bachtiar, M. 2013. Analisis faktor-faktor yang mempengharui permintaan konsumen terhadap listrik pada rumah tangga di desa Guntarano Kecamatan Tanantovea Kabupaten Donggala. Jurnal Katalogis, 1(3): 1-14.

Basri Faisal, Munandar Haris. 2009. Lanskap Ekonomi Indonesia. Jakarta: Kencana.

Bjorner, T. B., Mikael Togeby, and Jan Christiansen. 2006. Industrial Energy Demand : A Micro Panel Data Analysis. Institute of Local Government Studies-Denmark. Diakses dari http://www.akf.dk/deng 98/pdf/energy.pdf.

Boediono. 2000. Ekonomi Mikro. Yogyakarta: BPFE UGM.

Badan Pusat Statistik. 2018. Provinsi Bengkulu Dalam Angka 2018. Bengkulu : Badan Pusat Statistik. Diakses dari https ://bengkulu. bps.go.id/publication /2018/08/16/daf8f9376ee13daebada832f/provinsi-bengkulu-dalam-angka-2018.html.

2018. Kota Bengkulu Dalam Angka 2018. Bengkulu : Badan Pusat Statistik.

Diakses dari https: //bengkulukota. bps.go.id/ publication/2018
/08/16/58aa326a12224e782b73a8a7/kota-bengkulu-dalam-angka 2018.html.

Erfani, R. 2008. Analisis faktor-faktor yang mempengaruhi permintaan listrik di Kecamatan Muara Bangkahulu. Skripsi tidak diterbitkan. Bengkulu : Universitas Bengkulu.

Erikson, H.P.L 2011. Analisis Faktor-Faktor Yang Mempengaruhi Permintaan Konsumen Listrik Pada Rumah Tangga Sederhana (Studi Kasus pada Rumah Tangga Pelanggan 450 VA dan 900 VA di Desa Hutatoruan 1, Tarutung, Kabupaten Tapanuli Utara). Jurnal Ekonomi dan Bisnis, 2 (2): 30-36.

ESDM. 2017. Statistik Ketenagalistrikan 2017. Jakarta : Kementrian Energi dan Sumber Daya Mineral, Direktorat Jendral Ketenagalistrikan.

Fajriah. 2018. Analisis faktor-faktor yang mempengaruhi permintaan jumlah daya listrik rumah tangga di Kota Banda Aceh. Jurnal Ilmiah Mahasiswa (JIM) Ekonomi Pembangunan Fakultas Ekonomi dan Bisnis Unsyiah, 3 (4): 679-686. 
Ghozali, Imam. 2013. Analisis Multivarial dan Ekonometrika : Teori, Konsep dan Aplikasi dengan EVIEWS 8. Semarang: Badan Penerbit Universitas Diponegoro.

Gujarati, Damodar. 2003. Ekonometrika Dasar. Edisi Keenam. Jakarta: Erlangga

Kadir, Abdul. 2000. Distribusi dan Utilitas Tenaga Listrik. Jakarta : UIPress.

Kristianto, I. 2015. Analisis konsumsi listrik rumah tangga di Kecamatan Tembalang. Skripsi tidak diterbitkan. Semarang: Universitas Diponegoro. Diakses dari http://eprints.undip.ac.id/45434/1/04_KRISTIANTO.pdf..

Kotler dan Amstrong. 2001. Prinsip-Prinsip Pemasaran. Jakarta : Erlangga

Kuncoro, Mudrajad. 2003. Metode Riset Untuk Bisnis \& Ekonomi. Jakarta: Penerbit Erlangga.

Kusumaningtyas, R. 2017. Analisis konsumsi listrik rumah tangga di Pontianak Tenggara (Studi kasus : Komplek perumahan). Jurnal ilmiah Universitas Tanjungpura, 6 (3): 134-135

Lipsey, Richard, et.al. 2003. Pengantar Ilmu Ekonomi. Jakarta: PT Rineka Cipta

Nababan, 2015. Karekterisik Rumah Tangga yang Mempengaruhi Permintaan Energi Listrik Rumah Tangga Sederhana. Jurnal Ekonomi dan Bisnis, 16 (1): 61-74.

Nicholson, W. 2001. Teori Ekonomi Mikro I. Jakarta: Raja Grafindo Persada..

Nilagupta, 2013. Modelling Future Demand for Energy Resources : A Study of Residential Electricity Usage in Thailand. Dissertation. USA: Michigan State University. Diakses dari https://core.ac.uk/download /pdf/77619689 .pdf.

Nuryanti. 2007. Karakteristik Konsumsi Energi pada Sector Rumah Tangga di Indonesia. Jurnal Sekolah Tinggi Teknologi Nuklir, 10 (1): 171-182.

Oka \& Yasa, M. 2016. Analisis faktor-faktor yang mempengaruhi permintaan energi listrik di Provinsi Bali. E-Jurnal EP Unud, 8 (1): 211-238.

PT.PLN (PERSERO) UP3 BENGKULU. 2018. Laporan penjualan tenaga listrik. Bengkulu: PT. Perusahaan Listrik Negara, Unit Pelaksana Pelayanan Pelanggan Bengkulu.

Rahardja, P dan Manurung, M. 2001. Pengantar Ilmu Ekonomi (Mikro Ekonomi dan Makro Ekonomi). Edisi Ketiga. Jakarta: Fakultas Ekonomi Universitas Indonesia.

Reksohadiprodjo, S \& Pradono. 2002. Ekonomi Sumber Daya Alam dan Energi. Yogakarta : BPFE.

Reiss, P \& Matthew W,White. 2001. Household Electricity Demand, Revisited. Diakses dari http://www.nberg.org/.

Samuelson, Paul A dan Nordaus D, William. 2003. Ekonomi. Edisi 12 Jilid 2.

Jakarta: Penerbit Erlangga.

Setyawan, A. 2008. Analisis permintaan listrik rumah tangga (RI-900 VA) di kabupaten sukoharjo tahun 1981-2005. Skripsi tidak Diterbitkan. Surakarta: Universitas Muhammadiyah Surakarta. Diakses dari http://eprints.Ums.ac. id /821/.

Situmorang, Syafrizal H, et al. 2008. Analisis Data Penelitian Menggunakan Program SPSS. Medan : USU Press.

Sugiarto et al. 2000. Ekonomi Mikro Suatu Pendekatan Praktis. Jakarta : Gramedia Pustaka Utama.

Sugiyono. 2015. Metode penelitian kuantitaif, kualitatif dan R\&D. Bandung : Alfabeta.

2012. Metode Penelitian Pendidikan Pendekatan Kuantitatif dan Kualitatif, dan R\&D. Bandung: Alfabeta. 
2010. Metode Penelitian Kuantitatif dan Kualitatif. Bandung: Alfabeta.

Sukirno, Sadono. 2013. Pengantar Teori Mikroekonomi. Jakarta: PT. Rajagrafindo Persada. 2005. Pengantar Teori Mikroekonomi. Jakarta: PT. Rajagrafindo Persada.

Sumarsono, Sonny. 2007. Ekonomi Mikro. Yogyakarta: Graha Ilmu

Widarjono, Agus. 2010. Analisis Statistika Multivariate Terapan. Yogyakarta: UPP STIM YKPN.

Willenborg. 2005. Residential Demand for Electricity : A Consumer Panel Approach. Southern Economic Journal, 42 (2): 212-217.

Yoshiko. 2013. Analisis faktor-faktor yang mempengaruhi permintaan listrik rumah tangga di Kota Sangatta Kalimantan Timur. Skripsi tidak diterbitkan. Makasar: Universitas Hasanuddin. Diakses dari http:// repository.Unhas .ac.id/handle/ 123456789/6631.

Yusgiantoro P. 2000. Ekonomi Energi : Teori dan praktek, Jakarta : Pustaka LP3ES. 